\title{
EFEK PEMBERIAN INSENTIF DAN KOMITMEN DALAM UPAYA PENINGKATAN PRODUKTIVITAS KERJA KARYAWAN PT GELAEL SUPERMARKET MAKASSAR
}

\author{
Andi Siti Raodahtul Jannah ${ }^{1)}$ \\ E-mail: fauziyahnajla41@gmail.com \\ Politeknik Nusantara Makassar \\ Edy Jumady2)* \\ Sekolah Tinggi Ilmu Ekonomi Makassar (STIEM) Bongaya
}

\begin{abstract}
This study aims to analyze: (1) the effect of providing incentives to employee work productivity, (2) the effect of commitment to employee work productivity, (3) the effect of intuitive and commitment to the work productivity of employees of PT. Gelael Supermarket. This research is a descriptive quantitative research. The study population was all employees of PT. Gelael Supermarket as many as 150 employees with a sample of 65 respondents. Data collection using questionnaires and interviews, the sampling technique is simple random sampling, while the data analysis is done using multiple linear regression analysis. Results of the study: 1) Incentives had a significant positive effect on employee work productivity. 2) Commitment has a positive and significant effect on employee work productivity. 3) Simultaneous incentives and commitments affect employee work productivity.
\end{abstract}

Keywords: Incentives; Commitment; Employee Work Productivity 


\section{PENDAHULUAN}

Karyawan merupakan kumpulan orang/manusia yang berperan menentukan perusahaan dalam mencapai tujuannya, mulai dari kegiatan penyusunan rencana kerja, metode yang akan digunakan, kegiatan sistem pengendalian dan kegiatan pengambilan keputusan yang diterapkan sampai kepada kegiatan evaluasi berada di tangan karyawan. Guna meningkatkan produktivitas karyawan, maka pihak manajemen perusahaan harus memperhatikan beberapa hal, seperti penempatan karyawan pada suatu jabatan sesuai latar belakang pendidikan, keterampilan dan keahlian, seleksi penerimaan karyawan harus melalui suatu proses seleksi yang ketat, pemberian pendidikan dan komitmen (diklat) disesuaikan dengan jenis pekerjaan karyawan, serta kompensasi berupa insentif yang tepat dan layak sesuai pekerjaan dan tanggung jawab karyawan.

Pemberian kompensasi berupa insentif juga merupakan salah satu komponen penting dalam meningkatkan kinerja seorang karyawan. Mereka akan merasa lebih termotivasi untuk bekerja lebih keras lagi karena mereka menyadari ada suatu imbalan yang baik saat mereka mencapai sebuah prestasi atau kinerja yang baik atau bahkan lebih. Selain kompensasi insentif, komitmen karyawan juga perlu. Komitmen menjadi pengikat antara karyawan dengan perusahaan, komitmen karyawan itu sendiri didefinisikan sebagai suatu keadaan dimana seoarang karyawaan memihak pada organisasi dan tujuan organisasi serta bersedia untuk menjaga keanggotaan dalam organisasi yang bersangkutan (Pradana, 2014). Kurangnya komitmen pada karyawan dalam perbedayaan karyawannya berupa kepercayaan diri yang mengakibatkan juga menurunnya komitmen organisasi.

PT. Gelael Supermarket Makassar mengalami permasalahan kinerja karyawan. Berdasarkan wawancara yang dilakukan dengan Supervisior Pelayanan PT. Gelael 
Supermarket Makassar, diketahui bahwa sebagian karyawan kinerja kerjanya masih rendah, hal ini diindikasi dari karyawan yang belum bias memenuhi target. Untuk meningkatkan kinerja karyawan PT. Gelael Supermarket Makassar memberikan insentif sebagai pendorong untuk meningkatkan kinerja dan lebih disiplin. Istilah sistem insentif pada umumnya digunakan untuk menggambarkan rencana-rencana pembayaran upah yang dikaitkan secara langsung atau tidak langsung dengan berbagai standar kinerja karyawan atau profitabilitas organisasi. Insentif merupakan komponen dari kompensasi dan keduanya sangat menentukan dalam pencapaian tujuan dan sasaran organisasi secara keseluruhan.

PT. Gelael Supermarket Makassar adalah perusahaan yang bergerak di bidang jasa yang harus senantiasa memberikan yang terbaik bagi konsumen dan calon konsumen, disamping itu dituntut pula untuk selalu melakukan perubahan untuk memenuhi tuntutan konsumen. Langkah yang ditempuh pihak manajemen perusahaan untuk memenuhi tuntutan konsumen adalah peningkatan kinerja karyawa dengan cara menerapkan pemberian insentif dan penguatan komitmen kepada karyawan sebagai upaya untuk mendorong karyawan untuk bekerja lebih baik dan berkualitas.

Penelitian ini bertujuan untuk mengkaji pengaruh pemberian insentif dan komitmen baik secara parsial maupun simultan terhadap produktivitas kerja karyawan PT Gelael Supermarket Makassar.

\section{TINJAUAN TEORITIS}

\section{Pengertian Insentif}

Insentif merupakan bentuk kompensasi yang diberikan kepada seseorang sebagai upaya untuk mendorong seseorang bekerja lebih baik. Insentif bagi sebuah perusahaan menunjukkan sesuatu yang diberikan kepada karyawan sebagai tambahan 
penghasilan guna mendorong karyawan dapat bekerja lebih baik dan berkualitas sesuai kebijakan dari pihak manajemen bersangkutan.

Menurut Dessler (1997) menyatakan bahwa: Insentif diartikan sebagai tambahan penghasilan bagi karyawan selain gaji yang biasanya diberlakukan setiap bulan atau bersamaan dengan pelaksanaan gaji sebagai bentuk pendorong bagi karyawan untuk bekerja lebih baik dan berkualitas dalam mendukung tercapainya tujuan perusahaan. Simamora (2004) memberikan pengertian insentif adalah bentuk kompensasi yang diterima karyawan yang jumlahnya tidak tetap selain gaji dan dinyatakan sebagai tambahan penghasilan. Berdasarkan pengertian di atas, insentif adalah bentuk penghasilan yang diberikan kepada karyawan selain gaji yang bertujuan untuk mendorong karyawan bekerja lebih baik dan berkualitas. Menurut pengertian tersebut, insentif adalah imbalan jasa dalam bentuk uang yang diterima karyawan yang dinilai sebagai bagian dari hubungan kepegawaian, maka penetapan insentif sangat tergantung dari kebijakan manajemen yang diperlakukan sebuah lembaga atau organisasi.

\section{Komitmen Karyawan}

Menurut Steers (2008) dalam Pranoto (2016) mengatakan komitmen organisasi menjelaskan kekuatan relatif dari sebuah identifikasi individu dengan keterlibatan dalam sebuah organisasi. Komitmen organisasi Menurut Priansa (2014) dalam Rasyid (2016) komitmen organisasi adalah loyalitas karyawan terhadap organisasi yang tercemin dari keterlibatan yang tinggi untuk tujuan organisasi. Loyalitas karyawan tercermin melalui kesediaan dan kemauan pegawai untuk selalu berusaha menjadi bagian dari organisasi, serta keinginannya yang kuat untuk bertahan dalam organisasi. Menurut Mowday (1998) dalam Sopiah (2008) indikator komitmen organisasi yaitu:

a) Penerimaan terhadap tujuan organisasi.

b) Keinginan untuk bekerja keras.

86 
c) Hasrat untuk bertahan menjadi bagian dari organisasi.

\section{Produktivitas Karyawan}

Produktivitas adalah suatu hasil yang dicapai oleh seseorang dalam bidang pekerjaanya menurut kriteria tertentu yang berlaku untuk suatu pekerjaan tertentu dan dievaluasi oleh orang-orang. Produktivitas kerja menurut Siagian dalam Niam (2018) adalah kemampuan menghasilkan barang/jasa dari berbagai sumber daya dan kemampuan yang dimiliki oleh setiap pekerja/karyawan. Demikian pula menurut Serdamayanti dalam Jumady (2020) bahwa produktivitas kerja karyawan adalah hasil kerja secara kualitas dan kuantitas yang dicapai oleh seorang karyawan dalam melaksanakan tugasnya sesuai dengan tanggung jawab yang diberikan kepadanya. Indikator Produktivitas karyawan:

1) Kuantitas Kerja

2) Kualitas Kerja

3) Kreativitas Kerja

4) Pengetahuan Pekerjaan

Untuk lebih jelasnya kebijakan pemberian insentif dan komitmen yang dilakukan PT. Gelael Supermarket Makassar:

\section{Gambar 1 Kerangka Konseptual}

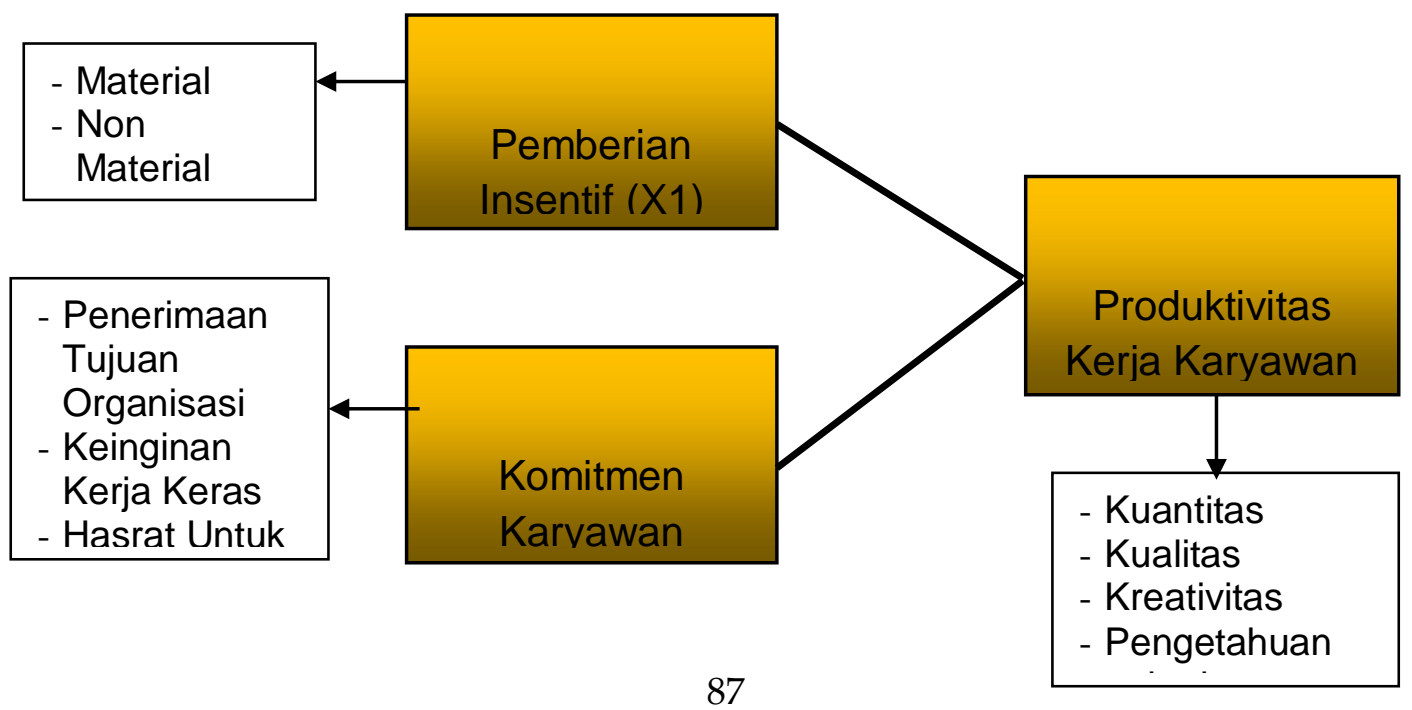

Jurnal Komunikasi Bisnis dan Manajemen

Vol.7 No.2 Juli 2020 


\section{Hipotesis}

Dalam penelitian ini model hipotesis dapat digambarkan sebagai berikut : (1) kompensasi insentif secara parsial berpengaruh signifikan tehadap produktivitas kerja karyawan pada PT Gelael Supermarket, (2) komitmen secara parsial berpengaruh signifikan tehadap produktivitas kerja karyawan pada PT Gelael Supermarket, (3) kompensasi insentif dan komitmen secara simultan berpengaruh signifikan tehadap produktivitas kerja karyawan pada PT Gelael Supermarket.

\section{METODE PENELITIAN}

Penelitian ini menggunakan pendekatan kuantitatif deskriptif. kuantitatif dengan menggunakan angka-angka, mulai pengumpulan data, penafsiran terhadap data tersebut serta tampilan hasilnya. Penelitian ini dilakukan di kantor PT. Gelael Supermareket Makassar. Populasi dari penelitian ini adalah seluruh karyawan PT. Gelael Supermareket Makassar yang berjumlah 150 orang. Rumus yang digunakan adalah pendapat Slovin, ukuran sampel dengan tingkat kesalahan 10\% adalah sebanyak 65 responsen.

Untuk menguji hipotesis yang diajukan dalam penelitian ini, maka metode analisis yang digunakan adalah analisis regresi linier berganda. Analisis ini bertujuan untuk menganalisis pengaruh Insentif dan komitmen terhadap kinerja karyawan. Adapun persamaan regresi linier berganda yang dipergunakan adalah sebagai berikut:

$$
Y=\beta_{0}+\beta_{1} X_{1} \beta_{2} X_{2}+e_{1}
$$




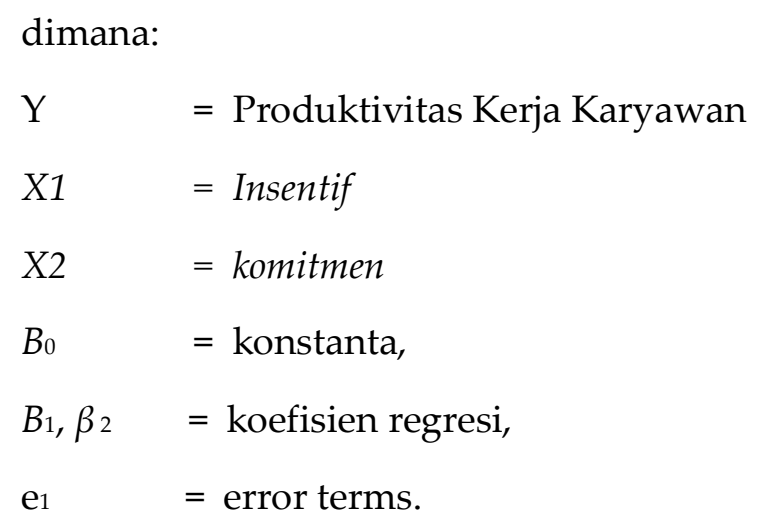

\section{HASIL PENELITIAN DAN PEMBAHASAN}

Pengujian Validitas Dan Realibilitas

Pengujian validitas dilakukan dengan menggunakan rumus korelasi product moment. $\mathrm{r}$ hitung diperoleh dari hasil output, nilai tersebut selanjutnya dibandingkan dengan nilai $r$ tabel dari buku statistik. Uji validitas dapat dilakukan dengan melihat korelasi antara skor masing-masing item dalam kuesioner dengan total skor yang ingin diukur, yaitu menggunakan Coefficient Correlation Pearson dalam SPSS. Jika nilai signifikansi (P Value) > 0,05 maka tidak terjadi hubungan yang signifikan. Sedangkan apabila nilai signifikansi (P Value) $<0,05$ maka terjadi hubungan yang signifikan.

Berdasarkan hasil uji validitas menunjukkan bahwa semua item pernyataan yang digunakan untuk mengukur variabel-variabel yang digunakan dalam penelitian ini mempunyai koefisien korelasi yang lebih besar dari $r$ tabel. Untuk sampel sebanyak 50 orang, yaitu 0,30. Dari hasil tersebut menunjukkan bahwa semua item pernyataan (indikator) adalah valid.

Uji reliabilitas digunakan untuk mengetahui konsistensi alat ukur, apakah alat ukur dapat diandalkan untuk digunakan lebih lanjut. Hasil uji reliabilitas dalam penelitian ini menggunakan koefisien cronbach alpha, dimana instrument dikatakan reliable jika memiliki koefisien cronbach alpha sama dengan 0,60 atau lebih. Semua hasil 
uji reliabilitas diatas menunjukkan bahwa semua variabel mempunyai koefisien Alpha yang cukup besar, yaitu di atas 0,60 sehingga dapat disimpulkan bahwa semua itemitem pengukur variabel dari kuesioner adalah reliable yang berarti bahwa kuesioner yang digunakan dalam penelitian ini merupakan kuesioner yang handal.

\section{Hasil Pengujian Regresi}

Pengaruh variabel pemberian insentif dan komitmen karyawan terhadap produktivitas karyawan pada PT. Gelael Supermarket Makassar dapat dilihat dari hasil pengujian regresi pada tabel dibawah ini:

Tabel 3. Hasil Pengujian Regresi

\begin{tabular}{|l|c|c|c|}
\hline \multicolumn{1}{|c|}{ Varabel } & Koef. Reg. & T-hit & T-tab \\
\hline Konstan & 3,361 & & \\
X1 = Pemberian Insentif & 0,163 & 2,194 & 1,782 \\
X2 = Komitmen Karyawan & 0,209 & 3,995 & 1,782 \\
\hline Korelasi Ganda (R) & 0,520 & \\
Koef. Determinasi (R $\left.{ }^{2}\right)$ & 0,271 & \\
\hline F-test & 11,497 & \\
F-tabel & 4,292 & \\
Sign. & 0,000 & \\
\hline
\end{tabular}

Sumber : Data diolah, 2020

Untuk mengetahui sejauhmana pengaruh pemberian insentif (X1) dan komitemen karyawan (X2) terhadap kinerja karyawan (Y) dapat digunakan analisis secara parsial yang dijelaskan melalui persamaan regresi yang diperoleh:

$$
Y=3,361+0,163 \times 1+0,209 \times 2+e i
$$

Persamaan ini dapat dijelaskan sebagai berikut: a) Nilai konstanta 3,361, artinya kinerja karyawan PT. Gelael Supermarket Makassar sebesar 3,361 satuan, dengan ini asumsi kinerja karyawan dalam keadaan konstan/tetap. b) Nilai koefisien regresi pemberian 
insentif $\left(X_{1}\right)$ 0,163, tingkat signifikan uji-t (p-value) sebesar 0,032 $(<0,05)$. Hasil ini membuktikan bahwa jika pemberian insentif meningkat 1\% maka kinerja karyawan PT. Gelael Supermarket Makassar secara signifikan akan meningkat sebesar 16,3\%. c) Nilai koefisien regresi komitmen karyawan $\left(\mathrm{X}_{2}\right)$ 0,209, tingkat signifikan uji-t (p-value) sebesar 0,000 (< 0,05). Hasil ini membuktikan bahwa jika komitmen karyawan meningkat 1\% maka kinerja karyawan PT. Gelael Supermarket Makassar secara signifikan akan meningkat sebesar 20,9\%.

\section{Uji Simultan (Uji F)}

Dari perhitungan diatas terlihat bahwa nilai F yang diperoleh adalah 11,497 untuk $\mathrm{F}$ tabel dengan $\alpha=0,05 \%$ dan masing-masing V1=2 dan V2= 47 diperoleh $\mathrm{F}$ Tabel = 4,292 karena F hitung lebih besar dari F Tabel maka Ho ditolak sehingga dapat disimpulkan bahwa pemberian insentif dan komitmen karyawan secara bersama-sama (simultan) berpengaruh secara signifikan terhadap kinerja karyawan pada PT. Gelael Supermarket Makassar. Besarnya pengaruh secara simultan sebesar 27,10\% adapun $72,90 \%$ dipengaruh oleh faktor-faktor diluar dari variabel pemberian insentif dan komitmen karyawan.

Hasil penelitian ini sejalan dengan penelitian Sari, R. P., \& Satrio, B. (2016) dan Shabrina, N. (2017) bahwa terdapat pengaruh positif dan signifikan antara pemberian insentif dan komitmen secara simultan dalam meningkatkan produktivitas karyawan.

\section{Uji Parsial (T-test)}

Berdasarkan hasil uji $\mathrm{t}$ parsial menunjukan hasil dari nilai $\mathrm{t}$ hitung setiap variable bebas, dan akan dibadingkan dengan nilai $\mathrm{t}$ tabel 1,96. Variabel pemberian insentif (X1) diperoleh t-hitung 2,194, karena $t$ hitung < $\mathrm{t}$ table yaitu 2,194<1,96. Maka Ho diterima dan $\mathrm{H} 1$ ditolak, yang berarti pemberian insentif (X1) berpengaruh positif dan signifikan terhadap produktivitas kerja karyawan PT Gelael Supermarket Makassar. Hasil penelitian ini didukung oleh Rompis, J., \& Sendow, G. (2019) dan 
Turangan, O. W., Kojo, C., \& Mintardjo, C. M. (2017) bahwa dakam implementasi pemberian insentif akan dapat membuat karyawan semangat serta termotivasi dan akhirnya memberikan efek produktif pada setiap karyawan.

Variabel komitmen (X2) diperoleh t-hitung 3,995, karena $t$ hitung $<\mathrm{t}$ tabel yaitu 3,995 < 1,96. Maka Ho diterima dan H1 ditolak, yang berarti komitmen (X2) berpengaruh positif dan signifikan terhadap produktivitas kerja karyawan PT Gelael Supermarket Makassar. Hasil penelitian ini didukung oleh Agustin, N., Nugraha, H. S., \& Budiatmo, A. (2015) dan Salim, M. I. (2013). Hasil penelitian ini juga membantah penelitian Niam, K., Wulan, H. S., \& Saputra, A. (2018) bahwa menunjukan hubungan antara komitmen organisasi dengan produktivitas kerja adalah negatif.

Besarnya koefisien determinasi $\left(\mathrm{R}^{2}\right)$ pada tabel diatas adalah 0,271 . nilai ini artinya, variasi yang terjadi pada kinerja karyawan (variabel Y) sebesar 0,271 dapat dijelaskan melalui perubahan-perubahan yang terjadi pada Komitemen Karyawan dan Pemberian Insentif (variabel X).

Besarnya pengaruh variabel lain yangh tidak dimasukkan ke dalam penelitian ini ( $\varepsilon i)$ adalah 0,779 yang berarti variasi yang terjadi pada tingkat kinerja perusahaan sebesar 77,9\% dapat dijelaskan melalui variabel-variabel diluar dari pemberian insentif dan komitemen karyawan,.

\section{KESIMPULAN}

Dikaitkan dengan rumusan masalah yang telah dirumuskan dalam penelitian ini, peneliti dapat menarik kesimpulan yang diperoleh dari hasil analisis dan pembahasan antara lain sebagai berikut: 1) Berdasarkan hasil analisis deskriptif dari hasil kuesioner dengan jumlah sampel sebanyak 50 responden menunjukkan bahwa semua indikator pernyataan yang disebar melalui kuesioner dalam frekuensi yang kuat. 2) Hasil uji hipotesis dengan menggunakan analisis regresi linear berganda 
menunjukkan bahwa variabel pemberian insentif (X1) dan komitmen karyawan (X2) secara parsial berpengaruh positif dan signifikan terhadap kinerja karyawan PT. Gelael Supermarket Makassar. 3) Hasil uji hipotesis dengan menggunakan analisis regresi linear berganda menunjukkan bahwa variabel pemberian insentif (X1) dan komitmen karyawan (X2) secara simultan berpengaruh positif dan signifikan terhadap kinerja karyawan PT. Gelael Supermarket Makassar.

\section{DAFTAR PUSTAKA}

Agustin, N., Nugraha, H. S., \& Budiatmo, A. (2015). Pengaruh Budaya Organisasi, Kepemimpinan Dan Komitmen Terhadap Produktivitas Kerja Karyawan (Studi Pada PT Astra International Tbk Daihatsu Cabang Majapahit Semarang). Jurnal Ilmu Administrasi Bisnis, 4(4), 208-219.

Halim, A. (2019). Analisis Faktor-Faktor Yang Berpengaruh Terhadap Kinerja Aparatur

Di Kantor Kecamatan Mariso Kota Makassar. Jurnal Manajemen, Bisnis dan Organisasi (JUMBO), 3(3), 130-139.

Dessler. (1997). Segi Manusia Dalam Manajemen. Aksara Baru. Jakarta.

Jumady, E. (2020). Peran Moderasi Disiplin Kerja Pada Pengaruh Kepemimpinan Terhadap Produktivitas Kerja Karyawan Perbankan Syariah Di Makassar. Islamic Banking: Jurnal Pemikiran Dan Pengembangan Perbankan Syariah, 5(2), 1-20. https://doi.org/10.36908/isbank.v5i2.110

Niam, K., Wulan, H. S., \& Saputra, A. (2018). Komitmen Organisasi, Gaya Kepemimpinan Dan Lingkungan Kerja Berpengaruh Terhadap Produktivitas Kerja Karyawan PT. Armando Tobacco Dengan Kedisiplinan Kerja Sebagai Variabel Intervening. Journal of Management, 4(4). 
Pradana, O. A. (2014). Pengaruh motivasi kerja dan komitmen organisasional terhadap kinerja karyawan (Studi pada karyawan bagian HRD PT. Arthawena Sakti Gemilang Malang). Jurnal Administrasi Bisnis, 7(2).

Pranoto, E., Haryono, A. T., \& Warso, M. M. (2016). Pengaruh Rekrutmen, Stress Kerja dan Pemberian Insentif Terhadap Produktivitas Kerja dengan Komitmen Organisasi sebagai Variabel Intervening Pada PT. Ungaran Sari Garment Unit III Congol Karangjati.". Journal of Management, 2(2).

Rasyid, M. N., Tobing, D. S., \& Syaharudin, M. (2016). Pengaruh Motivasi dan Insentif terhadap Kinerja Karyawan Melalui Komitmen Organisasi Pada Senyum Media Stationary Jember. BISMA: Jurnal Bisnis dan Manajemen, 10(3), 343-354.

Rompis, J., \& Sendow, G. (2019). Pengaruh Insentif, Turnover Dan Keterlibatan Kerja Terhadap Produktivitas Kerja Karyawan Cv. Segarindo Utama Minahasa. Jurnal EMBA: Jurnal Riset Ekonomi, Manajemen, Bisnis dan Akuntansi, 7(2).

Salim, M. I. (2013). Pengaruh Kepuasan Pada Sistem Bonus, Komitmen Organisasional dan Motivasi Kerja Terhadap Produktivitas Kerja Karyawan PT. Indra Jaya Banjarmasin. Agora, 1(3), 1347-1351.

Sari, R. P., \& Satrio, B. (2016). Pengaruh Insentif, Masa Kerja, Dan Komitmen Organisasi Terhadap Kinerja Karyawan. Jurnal Ilmu dan Riset Manajemen (JIRM), 5(8).

Sedarmayanti. (2009). Sumber Daya Manusia dan Produktivitas Kerja. Bandung: Mandar Maju. Lembaga penerbit Fakultas Ekonomi UI. Jakarta.

Shabrina, N. (2017). Pengaruh Komunikasi, Komitmen Organisasi Dan Pemberian Insentif Terhadap Kinerja Pegawai Pada Pt. Bank Muamalat Indonesia, Tbk Cabang Puri Indah. INOVASI, 4(2).

Simamora, Henry. (2004). Manajemen Sumber Daya Manusia. Penerbit YKPN, Yogyakarta.

94

Jurnal Komunikasi Bisnis dan Manajemen Vol.7 No.2 Juli 2020 
Turangan, O. W., Kojo, C., \& Mintardjo, C. M. (2017). Pengaruh Pemberian Upah dan Insentif terhadap Produktivitas Kerja Pegawai Kantor Badan Penanggulangan Bencana Daerah Provinsi Sulawesi Utara. Jurnal EMBA: Jurnal Riset Ekonomi, Manajemen, Bisnis dan Akuntansi, 5(3). 